\title{
Pomen odnosa z materjo pri urejanju zaposlitvenega statusa mladostnice z izkušnjo bivanja v vzgojni instituciji
}

\author{
Jovita Pogorevc Merčnik \\ Univerza na Primorskem in Center za socialno delo Koroška \\ jovita.pm@upr.si
}

\begin{abstract}
V prispevku predstavimo problematiko vključevanja mladostnikov v socialno okolje po zaključenem bivanju v vzgojni instituciji, s poudarkom na pomenu odnosa in podpore s strani staršev (matere) ter urejanja zaposlitvenega statusa. V empiričnem delu kvalitativne raziskave predstavimo primer vključevanja mladostnice $v$ socialno okolje po zaključenem bivanju v vzgojni instituciji. Analiza podatkov, pridobljenih prek pisanja življenjske zgodbe kaže, da je mladostnica kljub zaključeni srednješolski izobrazbi opravljala delo čistilke, najprej nelegalno, kasneje preko podjemne pogodbe, ter izražala željo po vključitvi na študij socialne pedagogike, kar jo je bilo strah uresničiti. Mati se za mladostnico dolgo ni zanimala. Kasneje, ko je mati uspešno zaključila zdravljenje odvisnosti od alkohola, se je njun odnos izboljšal. Na podlagi mladostničinih izjav zaključimo, da slaba podpora in odnos matere do mladostnice vplivata na njene odločitve na področju zaposlovanja in izobraževanja v smeri slabe uporabe lastnih kompetenc.
\end{abstract}

Ključne besede: vzgojni zavod/zaposlovanje/izobrazba/odnos z materjo

\section{Uvod}

V prispevku obravnavamo populacijo mladostnikov, ki so del svojega življenja preživeli v vzgojni instituciji in se po zaključenem bivanju v njej vključujejo v socialno okolje. Raziskujemo prehajanje iz okolja (vzgojni zavod), kjer imajo mladostniki pri vsakodnevnih opravilih in tudi širše zagotovljeno pomoč, v okolje (življenje v socialnem okolju), kjer morajo zase poskrbeti sami.

Prehajanje v samostojno življenje po zaključenem bivanju v vzgojni instituciji poteka na več področjih; urejanje bivanjskih razmer, zaposlitev, šolanje, odnosi $z$ družino ...V pričujočem prispevku bomo prehod mladostnice iz institucionalne oskrbe $v$ socialno okolje predstavili na področju urejanja zaposlitvenega oz. izobrazbenega statusa.

\section{Odhod mladostnikov iz vzgojnega zavoda}

V slovenskem prostoru je bivanje otroka oz. mladostnika v vzgojnem zavodu omejeno na največ tri leta. Čeprav ima sodišče možnost podaljšanja ukrepov 
za varovanje koristi otroka, se to enkrat zaključi, če ne prej, z dopolnjenim 18. letom starosti ali s pridobitvijo polne poslovne sposobnosti, ko sme otrok oz. mladostnik v zavodu ostati le, če v to pisno privoli. Bivanje v vzgojni instituciji se tako, $v$ skladu z zakonskimi določili, preneha in je lahko popolnoma neodvisno od uspešnosti zaključenega vzgojnega programa ter šolanja.

Za obdobje osamosvajanja je znano, da je relativno stresno že samo po sebi (Radić Bursać in Jeđud Borić 2013, 249) in običajno poteka kot dvostopenjski proces, ki zajema razvoj lastnega razmišljanja in vpliv sprememb, ki se dogajajo v družbi; pri mladostnikih, ki pa imajo izkušnjo bivanja v instituciji, je proces osamosvajanja tristopenjski, pri čemer tretjo stopnjo predstavlja vstop v socialno okolje oz. izstop iz institucije (Malmberg in Trempala 1997 v Žižak, Koller-Trbovič in Jeđud 2005). Zaradi tega se z bolj tveganim in težjim procesom osamosvajanja soočajo otroci in mladostniki, ki so bili ločeni od družine (Radić Bursač in Jeđud Borić 2013, 249). Odhod iz zavoda lahko za mladostnike predstavlja veliko sprememb, povezanih s strahom in z negotovostjo, saj mu zavodska oskrba predstavlja varno okolje, kjer so postavljena pravila in dnevna rutina, kjer gojijo zdrave odnose, vzgojitelj in ostali mladostniki pa jim predstavljajo nadomestno družino (Krajnčan in Šoln Vrbinc 2015, 27). Prehod mladostnikov iz varne institucionalne oskrbe $v$ družbo oz. neodvisnost je problematičen, še posebej na področju financ, šolanja, zaposlovanja in dogovarjanja o namestitvi (Harder, Knorth in Kalverboer 2011). ${ }^{1}$

Vključevanje mladostnikov $v$ socialno okolje je, po zaključenem bivanju v vzgojni instituciji, z različnih vidikov težavno oz. je ta skupina mladostnikov ranljiva in potrebuje več podpore, vzpodbude in pomoči v procesu osamosvajanja, kot pa jo potrebujejo mladostniki, ki ob urejanju življenja na svojem uživajo podporo družine, zaradi česar se pri njih ne sprašujemo o najprimernejšem času odhoda iz izvorne družine (Höjer in Sjöblom 2011), tako kot se sprašujemo pri mladostnikih, ki so bivali v vzgojni instituciji oz. je čas bivanja $v$ instituciji zanje normativno omejen.

\section{Vračanje $\mathbf{v}$ družinsko okolje in pomen odnosa s starši po odhodu iz vzgojnega zavoda}

Mladostniki se po odhodu iz institucije največkrat vračajo $v$ okolje, od koder so bili izločeni, kar so prepoznali v več raziskavah. $V$ izraelski je npr. med anketiranimi mladostnicami kar $68 \%$ takšnih, ki so po zaključenem bivanju v instituciji živele doma oz. pri starših partnerja (Dutta 2017), v nizozemski o vračanju $k$ staršem po odhodu iz institucije poroča polovica vprašanih mla-

\footnotetext{
${ }^{1}$ Raziskava, v kateri so prišli do navedenih ugotovitev, je bila opravljena na Nizozemskem.
} 
dostnikov (Harder, Knorth in Kalverboer 2011). V družinskem okolju, kamor se mladostnik vrne, so običajno še vedno isti negativni vplivi, kot so bili pred odhodom v zavod (Kovačević 1982), zaradi česar mladostniki težko ohranjajo novonaučena vedenja in ravnanja. Večkrat se tako dogaja, da se morajo mladostniki z izkušnjo zavodske oskrbe na svojem kmalu znajti sami in običajno brez podpore družine (Groing in Sting 2019, 42).

$\checkmark$ povezavi z odnosom s starši so $v$ hrvaški raziskavi starejšega datuma (Žižak 1982) ugotovili, da se odnos mladostnikov do družine po zaključenem bivanju v zavodu, glede na odnos pred prihodom v institucijo, ni spremenil, iz česar avtorica povzema, da v času namestitve otroka oz. mladostnika $\checkmark$ vzgojno institucijo delo s starši ni potekalo ali pa je bilo prešibko, da bi do sprememb v odnosih lahko prišlo, kar pa je nujno, saj mladostniki z izkušnjo bivanja v instituciji iz različnih držav navajajo, da imajo izvorne družine zanje velik pomen (Jackson in Cameron 2012). ${ }^{2}$

Kljub vsemu pa vzpostavljanje odnosa s starši po zaključenem bivanju v vzgojni instituciji ni edini odnos, za katerega si mladostniki prizadevajo oz. je zanje pomemben. Ob pregledu zagotavljanja socialne podpore mladim $v$ času odhoda iz institucije ter oblikovanja samostojnega življenja $v$ več $d r-$ žavah so ugotovili, da je dosti mladostnikov, ki po odhodu iz institucije velik pomen za zagotavljanje podpore pripisuje partnerjem oz. si hitro po odhodu iz institucije ustvarijo lastno družino (Hiles idr. 2013). ${ }^{3}$ Ustvarjanje lastne družine je $v$ Jordaniji eden izmed načinov, da se $v$ družbi po zaključenem bivanju $v$ instituciji izognejo stigmi, saj biti poročen tam pomeni, da je posameznik odrasel. Delež mladostnikov, ki se poroči, v opravljeni raziskavi znaša $27 \%$ (Ibrahim in Howe 2011).

Ker se pri vključevanju v socialno okolje mladostniki srečujejo s težavami, je eden od kritičnih korakov za učinkovito socialno integracijo tudi priprava na odhod iz institucije (Dutta 2017), kar je tudi eden poglavitnih ciljev vzgojne ustanove (Krajnčan in Šoln Vrbinc 2015, 27). Zaradi tega se že s samo obravnavo $v$ zavodu mladostnikom trudijo omogočiti objektivno ugoden status na področju šolanja, vzgojnega delovanja, vezi s starši, vezi s centrom za socialno delo, kar prispeva tudi k uspešni integraciji v družbenem prostoru po zaključenem bivanju v instituciji (Bujanović-Pastuavić in Bašić 1982), vendar ni nujno, da je to za uspešno vključevanje v socialno okolje dovolj.

${ }^{2}$ Podatek izhaja iz raziskav, opravljenih v Angliji in Španiji ter na Danskem, Švedskem in Madžarskem.

${ }^{3}$ Pregledne raziskave so bile opravljene v letih 2001-2013, večina v Angliji in ZDA, nekaj manj na Škotskem in v Avstraliji, sledijo še Severna Irska, Romunija, z najmanjšim številom raziskav pa so Velika Britanija, Izrael, Jordanija Španija in Švedska. 
Za mladostnike, ki se po zaključenem bivanju v izvendružinski oskrbi vključujejo v socialno okolje, dodatno oviro predstavlja še dejstvo, da so vzgojni zavodi med prebivalstvom deležni predsodkov, zaradi česar otroci in mladostniki, ki so bili nameščeni vanje, izkusijo zavračanja sosedov, naletijo na nezaupanje in dvom pri prijateljih, sošolcih ter učiteljih in so v družbo sprejeti s sumničavostjo (Krajnčan 2006, 79). Vzgojni zavodi na Slovenskem so obremenjeni s hipoteko preteklosti, saj predstavljajo sintezo srednjeveških sirotišnic, mladoletniških zaporov ter internatov za srednjeveško mladino, ki se je šolala zunaj kraja stalnega bivališča (Skalar 1995, 25). Zaradi tega lahko uspešno vključitev v družbo ovira tudi dejstvo, da so vzgojni zavodi v javnosti diskriminirani, otroci in mladostniki stigmatizirani, vzgojne intencije pa doživljajo kot kazen, sodbo kot posledico neke lastne krivde (Krajnčan 2006, 15).

\section{Pomen izobrazbenega in zaposlitvenega statusa po odhodu iz vzgojnega zavoda}

Ob zaključku bivanja v institucionalni oskrbi oz. ponovnem vključevanju v socialno okolje ima za mladostnike velik pomen izobrazba, saj je to osnova za iskanje službe oz. zaposlitve, kar si morajo mladostniki po zaključenem bivanju v instituciji zagotoviti za lastno preživetje (Arnau-Sabatés in Giligan 2015). Zaradi tega o izobraževanju ter izobrazbenih kvalifikacijah mladostnikov z izkušnjo bivanja v institucionalni oskrbi težko razmišljamo nepovezano z zaposlitvijo oz. zaposlitvenimi kvalifikacijami.

Za mladostnike $z$ izkušnjo bivanja $v$ instituciji se ugotavlja, da je bolj kot vključevanje $v$ daljše izobraževanje zgodaj promovirana pridobitev izobrazbe in kvalifikacij, in sicer iz razloga, da bi se ti mladostniki, ki bivanje $v$ zavodu zaključijo v zgodnjih letih, čimprej vključili na trg dela s poklicno kvalifikacijo, pa tudi zato, ker jim strokovnjaki ne zaupajo, da bodo daljše izobraževanje uspešno končali, pri čemer so interesi mladih spregledani (Groing in Stein 2019).

O tem poročajo tudi sami mladostniki z izkušnjo bivanja v vzgojni instituciji. Mladostniki na Madžarskem pravijo, da so bili usmerjeni v odločitev za kratke poklicne tečaje, s katerimi pridobijo le nizko stopnjo kvalifikacij, ki jih niso nujno pripeljali do zaposlitve, prav tako izobraževanje ni potekalo v skladu z njihovimi zmožnostmi (Jackson in Cameron 2012). Omejitev na izučitev neke spretnosti (poklicna šola), ki vodi v hitro finančno neodvisnost ter tudi neodvisnost od socialnovarstvene pomoči, se prepoznava pri mladostnikih, ki zapuščajo vzgojne institucije v Avstriji (Groing in Stein 2019), med njimi je $70 \%$ zaposlenih ali v poklicnem usposabljanju, $28 \%$ je brezposelnih. Podobno velja tudi za jordanske mladostnike, pri katerih jih je ob odhodu iz in- 
stitucije $61 \%$ brez poklicne kvalifikacije, med zaposlenimi mladostniki pa večina opravlja delo, kjer ni potrebnih posebnih veščin (nekvalificirano delo), za kar prejemajo nizko plačilo (Ibrahim in Howe 2011). Za Anglijo so za obdobje 2013-2014 ugotovili, da delež 19-letnikov, ki niso vključeni ne v izobraževanje ne v usposabljanje ali zaposlitev, znaša $15 \%$, med njimi pa je $41 \%$ takšnih, ki imajo izkušnjo bivanja v institucionalni oskrbi (National Audit Office 2015).

Tudi rezultati primerjalne študije, $v$ kateri so primerjali izobrazbo mladostnikov z izkušnjo bivanja v instituciji iz Španije, Danske, Anglije, Madžarske in Švedske, so prepoznali, da je v vseh državah visok delež mladih, ki so zaključili srednjo šolo, z izjemo Madžarske, kjer jih je največ zaključilo le obvezno izobraževanje (Jackson in Cameron 2012). Ob tem pa je zanimiv podatek, da ti mladostniki dosežejo višje izobrazbene kvalifikacije kot njihovi starši (Groinig in Stein 2019). ${ }^{4}$

V zvezi z zaposlovanjem mladostnikov z izkušnjo bivanja v instituciji za slovenski prostor razpolagamo le s starejšimi podatki, ki kažejo, da se jih velik delež zaposli v družbenem sektorju $(56,1 \%), 24,2 \%$ pa je takšnih, ki se niti ne zaposlijo niti se ne šolajo (Škoflek 1989, 279).

Zagotovo je prav, da se po odhodu iz institucije mladostniki vključijo v aktivnosti na trgu dela ter tudi da jim država pri tem pomaga. $V$ slovenskem sistemu tovrstno pomoč nudi Zavod za zaposlovanje. V primeru brezposelnosti Zavod mladostniku pomaga pri iskanju primerne oz. ustrezne zaposlitve oz. mu v primeru nedokončane izobrazbe ali interesa po dodatnih poklicnih kvalifikacijah omogoči, da le-to pridobi, kar Zakon o urejanju trga dela (2010) v okviru ukrepov aktivne politike zaposlovanja tudi omogoča. V zvezi s tem je potrebno pojasniti, da je lahko oseba, ki je kot brezposelna prijavljena na Zavodu za zaposlovanje, v skladu z veljavno zakonodajo (Zakon o uveljavljanju pravice iz javnih sredstev (2010) ter Zakon o socialno varstvenih prejemkih (2020)) ob izpolnjevanju vseh potrebnih pogojev upravičena do denarne socialne pomoči, ki trenutno znaša 402,18 EUR (Ministrstvo za delo, družino, socialne zadeve in enake možnosti b. I.), kar naj bi bilo za osnovno preživetje, tudi mladostnikov po zaključenem bivanju v instituciji, dovolj. ${ }^{5}$

Ker so izobrazbene kvalifikacije mladostnikov ob odhodu iz institucije večkrat pomanjkljive oz. nedokončane, sklepamo, da bi jim vključitev v oblike pomoči, ki so na voljo v okviru aktivne politike zaposlovanja, lahko koristila v smeri izboljšanja možnosti za primernejšo zaposlitev.

Ob pregledu programov, ki so v »Katalogu aktivne politike zaposlovanja«

\footnotetext{
${ }^{4}$ Podatek izhaja iz raziskave, opravljene v Avstriji.

${ }^{5} \mathrm{Ob}$ predpostavki, da ima mladostnik urejene bivalne razmere.
} 
(Ministrstvo za delo, družino, socialne zadeve in enake možnosti 2021) in ki omogočajo vključitev tudi mladostnikom po zaključenem bivanju v instituciji, smo zaznali, da teh ni veliko. Ob upoštevanju starostnega pogoja do 29 let ter s ciljem povečanja zaposljivosti in izboljšanja pogojev za vstop na trg dela z dvigom usposobljenosti je možna le vključitev v neformalno izobraževanje in usposabljanja za mlade, program usposabljanja na delovnem mestu za mlade ter delovni preizkus za mlade. Za mlajše odrasle, stare med 15 in 26 let, ki so brezposelni, pa je na voljo še program Projektno učenje mlajših odraslih (PUM), katerega namen je, da vključeni pridobijo veščine, ki olajšajo pot do zaposlitve, ali se vrnejo v izobraževanje, namen pa so tudi dvig splošne izobraženosti, formirane poklicne identitete in socialno-kulturno delovanje. Poleg teh pa se mladostniki z izkušnjo bivanja v instituciji lahko vključijo še v nekatere programe, kjer starostne omejitve ni.

Ob pregledovanju dokumentov, ki se nanašajo na aktivno politiko zaposlovanja - to so Zakon o urejanju trga dela (2010), »Katalog aktivne politike zaposlovanja« (Ministrstvo za delo, družino, socialne zadeve in enake možnosti 2021) in ॥Smernice za izvajanje ukrepov aktivne politike zaposlovanja za obdobje 2021-2025" (Ministrstvo za delo, družino, socialne zadeve in enake možnosti 2020) -, smo na več mestih zasledili zapis, da so ukrepi aktivne politike zaposlovanja namenjeni ranljivi skupini prebivalstva, kjer pa niso navedeni mladostniki z izkušnjo bivanja v vzgojni instituciji.

\section{Raziskovalna metodologija}

\section{Raziskovalni problem in cilji}

V Sloveniji imajo mladostniki z izkušnjo bivanja v instituciji v skladu z normativno ureditvijo enake možnosti za zaposlitev ter sodelovanje z Zavodom za zaposlovanje kot ostali mladostniki, ki za izkušnjo normalnega družinskega življenja niso bili prikrajšani. Prav tako je področje vključevanja mladostnikov $v$ socialno okolje po zaključenem bivanju v vzgojni instituciji slabo raziskano. Raziskava $v$ slovenskem prostoru, $v$ kateri so se $v$ okviru prehoda mladostnikov iz vzgojne institucije $v$ socialno okolje ukvarjali tudi s področjem zaposlovanja, je iz leta 1989 (Škoflek) in je edina, ki smo jo zasledili.

$S$ pričujočo raziskavo želimo ugotoviti, kakšne so izkušnje s sodelovanjem z Zavodom za zaposlovanje oz. z vključitvijo na trg dela ter zaposlitvene in izobraževalne izkušnje mladostnice, ki ima izkušnjo bivanja v vzgojni instituciji. Prav tako želimo ugotoviti, ali je odnos s starši (predvsem materjo) pri mladostnici po odhodu iz institucije vplival na dogajanje na področju njene zaposlitve in izobraževanja.

$\checkmark$ povezavi s tem so $v$ empiričnem delu postavljeni naslednji cilji: 
- ugotoviti, kakšne izkušnje na področju sodelovanja z Zavodom za zaposlovanje je mladostnica pridobila do danes;

- ugotoviti, kako je potekala mladostničina vključitev na trg dela;

- ugotoviti, kako se je oblikoval mladostničin zaposlitveni status oz. izobraževalne reference;

- ugotoviti vpliv odnosa s starši (matere) na oblikovanje poklicnega oz. izobrazbenega statusa mladostnice.

\section{Raziskovalni pristopi}

Raziskava je kvalitativna, za katero je značilna interpretativna paradigma, kjer gre za razumevanje in interpretacijo raziskovalnih situacij, procesov, dogajanj, odnosov, reakcij, interakcij, ravnanj (Sagadin 2001, 12). Pri raziskovanju skušamo ohranjati hermenevtični pristop, ki je temelj za interpretativno razumevanje oz. iskanje pomena in poudarja pomen upoštevanja konteksta (Patton 2002, 114).

Pri raziskovanju bomo uporabili študijo primera, ki zajema pripoved življenjske zgodbe (angl. life story), ki je nekakšna rekonstrukcija osebnih izkušenj (Goodson 1992, 243, v Cencič 2001, 52). Uporabili bomo podatke, ki jih bo vključena $v$ raziskavo posredovala s pripovedovanjem.

\section{Predstavitev sodelujoče $v$ raziskavi}

$\checkmark$ raziskavi je sodelovala mladostnica, ki je bila nameščena $v$ vzgojni zavod, kjer je bivala tri leta (2006-2009), danes je stara 26 let (r. 1994). Po končanem ukrepu namestitve v vzgojno institucijo se mladostnica ni vrnila v kraj, kjer je bivala prej, pač pa se je odselila v drugo mesto, kjer je živela s teto, medtem ko se starša zanjo nista zanimala. $V$ tem mestu je spoznala partnerja, $s$ katerim je v partnerski zvezi še danes. Živi skupaj z njim ter dvema otrokoma. Njen oče je pokojni, mati si je uredila svoje življenje, z mladostnico sta $v$ rednih stikih.

Sodelujoči v raziskavi zagotavljamo anonimnost na način, da ne navajamo njenega imena, ampak jo poimenujemo z izmišljenim imenom Ula, ne navajamo njenega kraja bivanja in drugih krajevnih območij, ki se omenjajo $v$ razpravnem delu.

\section{Proces zbiranja podatkov}

Z mladostnico smo se prvič dogovorili za pisanje njene življenjske zgodbe v letu 2014; pisala je o svojem načinu življenja v takratnem pozavodskem obdobju. Predstavila je tudi svoj zaposlitveni status, pripovedovala je o kvaliteti svojega življenja in odnosih z njej pomembnimi osebami, prav tako tudi o 
svojem pogledu na vzgojno institucijo in pomenu, ki ga je le-ta imela zanjo $\checkmark$ času pisanja življenjske zgodbe.

Kontakt z mladostnico smo ponovno vzpostavili leta 2021, in sicer s prošnjo, da pripravi zapis življenjske zgodbe za zadnjih sedem let, pri čemer je bila naprošena, da se pri pripovedovanju posveti predvsem področju svojega izobraževanja, zaposlovanja, sodelovanja z Zavodom za zaposlovanja ter aktivnostmi na trgu dela. Mladostnica je imela na voljo dva tedna, da pripravi zapis. $V$ dogovorjenem roku ga je poslala po elektronski pošti. $V$ skladu s predhodnim dogovorom smo nejasnosti, dvoumnosti ter morebitno napačno razumevanje vsebin življenjske zgodbe preverjali preko aplikacije Messenger.

Podatke smo obdelali s pomočjo postopka kodiranja, pri čemer smo posameznim izjavam življenjske zgodbe najprej določili kode, nato pa še pojme, ki so $\mathrm{v}$ besedilu podčrtani. Uporabili pa smo tudi izjave mladostnice, ki so ostale nespremenjene in so $v$ besedilu zapisane s poševno pisavo.

\section{Analiza rezultatov}

\section{Področje izobraževanja in zaposlovanja}

Iz zapisa življenjske zgodbe, ki jo je Ula podala v letu 2014, ko je imela 21 let, izhaja, da je institucionalno varstvo zapustila $z$ nedokončano srednješolsko izobrazbo, šolanje pa je nadaljevala po koncu bivanja v zavodu. Želela si je tudi študirati, in sicer socialno pedagogiko, vendar se na študij takrat ni vpisala, saj je kmalu po opravljeni maturi rodila prvo hčerko. Tako je leta 2014 živela s partnerjem in hčerko $v$ večjem mestu. Njen partner je istega leta dobil službo, Ula pa je veliko delala nelegalno, predvsem $v$ gostinstvu. $V$ povezavi s tem pove, da se jima »ni splačalo prenehati prejemati denarne socialne pomočik.

Čez leto dni (2015) je njen partner ostal brez zaposlitve, ker se mu je iztekla pogodba, brezposelna je bila tudi Ula. Še vedno sta bila prejemnika denarne pomoči, poleg tega pa je njen partner delal nelegalno (poliranje avtomobilov), dnevno sta zaslužila 300 evrov.

Ula v tem obdobju pripoveduje o »svojih sanjah o nadaljevanju šolanja«, ki jih ni upala uresničiti, videla je ovire, za katere pove, da so bile močnejše kot njene želje (pot do Ljubljane, ni imela avta, $v$ Ljubljani ni mogla živeti, imela je otroka ...), zaradi česar si izobraževanja ni upala nadaljevati.

Še $v$ istem letu je ponovno našla zaposlitev, tudi tokrat nelegalno delo, in sicer kot čistilka v gostinskem lokalu, poleg tega je čistila še zasebna stanovanja. Pri tej zaposlitvi ji je bilo všeč, da si je lahko sama določala urnik dela ter da je dobro zaslužila. Razmišljati je pričela, da bi odprla svoj s. p., a je ugotovila, da se to ne bi splačalo, saj bi imela več stroškov kot dobička. 
Leta 2016 je Ula drugič zanosila. Po rojstvu drugega otroka je delo opustila, ker je bila zaradi dela veliko odsotna. Takrat si je želela, da bi imela službo, kjer bi svoje delo opravila ter potem imela še dovolj časa za družino. Partner se je $v$ tem letu ponovno zaposlil, in sicer za nedoločen čas, to zaposlitev ima še danes. Ula je povedala, da so bili njegovi dohodki visoki. Delo je $v$ tem času ponovno dobila tudi sama, preko poznanstev, pri istem delodajalcu je bila najprej zaposlena preko podjemne pogodbe, potem preko pogodbe za polovični delovni čas, trenutno pa zaradi razmer $v$ državi (epidemija) ponovno dela samo preko podjemne pogodbe. Zaposlena je kot čistilka. Še vedno sodeluje $z$ Zavodom za zaposlovanje in upa, da bi tudi z njihovo pomočjo lahko našla redno delo. Do denarne socialne pomoči kot družina niso več upravičeni, glede česar pravi: "Sedaj ko so partnerjevi dohodki toliko višji, do socialne pomoči nismo več upravičeni, je praktično vseeno oz. nisem tako omejena, kot sem bila prej, ko si nismo upali odpovedati tej coni ugodja socialne pomoči.«

Preko aplikacije Messenger nam je Ula poročala še o svojem sodelovanju z Zavodom za zaposlovanje, saj v pripovedi o tem ni pisala. Navaja, da je z njimi sodelovala na način, da je hodila na razgovore ob dogovorjenih terminih, o napotitvah $\mathrm{k}$ delodajalcem s strani Zavoda ne poroča, pove, da se je vedno dogovorila, da je bilo iskanje zaposlitve prepuščeno njej. Pove, da je bila poleg terminov za razgovore na Zavodu napotena še na karierno središče ter na triurne delavnice. Kakšna je bila vsebina delavnice, se ne spomni.

Ula je zavodsko oskrbo zapustila v letu 2009, do leta 2014 ne vemo, kaj se je pri njej dogajalo na področju zaposlitve, za leto 2014 pa navaja, da je zaposlitev sicer imela, a je bilo to nelegalno delo. $O$ rednem delovnem razmerju poroča šele $v$ zadnjem obdobju, ki $v$ časovnem trajanju ni natančno opredeljeno. Poleg opravljanja nelegalnega dela je $v$ preteklosti uveljavljala še denarno socialno pomoč, kar kaže, da je v materialnem smislu zase in svojo družino dobro poskrbela.

Ula se je v obdobju po zaključenem bivanju v vzgojni instituciji sicer podala v nelegalen način preživljanja, $s$ katerim je poskrbela za svoj materialni položaj, česar ji pravzaprav ne moremo pretirano očitati, saj v današnji kapitalistično, tržno usmerjeni družbi mladostniki in mlajši odrasli kljub ustrezni izobrazbi in motiviranosti za delo slednjega pogosto ne dobijo, možnost socialne in poklicne integracije za populacijo iz vzgojnih zavodov pa je toliko manjša (Krajnčan 2006, 75), česar se je verjetno zavedala tudi Ula. Svoj zaposlitveni status ima danes urejen, zaposlena je preko podjemne pogodbe ter tudi denarne socialne pomoči ne prejema več.

Iz besedila, v katerem poroča o sodelovanju z Zavodom za zaposlovanje, 
razumemo, da ni želela veliko pomoči s strani Zavoda, saj je zaposlitev želela iskati sama. Iz tega povzemamo, da je to želela, da je lahko opravljala nelegalno delo ter sta s partnerjem lahko prejemala še denarno socialno pomoč. Sodelovanje z Zavodom je vzdrževala $v$ tolikšni meri, kot je bilo potrebno, da je ohranjala status aktivne iskalke zaposlitve, kar ji je omogočilo prejemanje denarne socialne pomoči. V povezavi s sodelovanjem z Zavodom večjih pričakovanj po zagotavljanju pomoči z njihove strani (npr. napotovanje v izobraževanje, delavnic ...) ni izražala, za vključevanje na trg dela se je, pretežno v okviru nelegalnih zaposlitev, trudila sama. Prav tako je si je sama poiskala redno zaposlitev.

Pa vendar v zapisu njene življenjske zgodbe bode $v$ oči podatek, da ima zaključeno srednješolsko izobrazbo - program varuh predšolskih otrok ter si želi študirati socialno pedagogiko, ves čas po zaključenem bivanju v vzgojnem zavodu pa poroča, da opravlja delo čistilke, za katero formalna izobrazba ni potrebna. Ocenjujemo, da bi lahko, glede na zaključeno izobrazbo, poiskala kvalificirano zaposlitev, a v besedilu njeno razmišljanje ali interes $v$ tej smeri nista niti nakazana. Prav tako ocenjujemo, da bi, glede na dejstvo, da je uspešno zaključila dokaj zahteven srednješolski program, zmogla uspešno zaključiti tudi željen študij.

Zapis Uline življenjske zgodbe vsebuje tudi podatke, iz katerih je razvidno, da je tudi po zaključenem bivanju $v$ instituciji uživala slabo podporo staršev, predvsem matere, ter da si je za nasprotno močno prizadevala. To nas usmerja na sklepanje, da sta izbira vrste dela ter strah pred nadaljevanjem izobraževanja povezana z nizko podporo staršev (matere), lastnimi nizkimi pričakovanji ter izkušnjami zlorabe in zanemarjanja v izvorni družini, ki so jih kot ovire, s katerimi se soočajo mladi pri doseganju izobrazbe, prepoznali vodje socialnih služb na Švedskem (Höjer in Sjöblom 2011).

Povezanost med odnosom z materjo in izbiro dela, ki ga Ula opravlja, ter strahom pred nadaljevanjem šolanja predstavljamo v naslednjem poglavju, kjer analiziramo del življenjske zgodbe, ki pripoveduje o njenem odnosu z materjo.

\section{Odnos z materjo}

Ulin reflektivni pogled, ki ga glede bivanja v zavodu v svoji življenjski zgodbi izraža leta 2014, kaže pozitivna občutja in doživljanja (»ko odideš od tam, ugotoviš, da pa le niso bili tako slabi«; »bili so edini, ki so te razumeli«; »bili so pripravljeni prisluhniti tvojim problemom «; »dandanes jih spoštujem«), kljub temu pa svoje razmišljanje $v$ povezavi s tem zaključi z mislijo, da svojemu otroku ne želi dati tega, kar so njej dali njeni starši, kar se nanaša na bivanje 
$v$ zavodu. Iz tega razumemo dvoje: Ula sicer pri sebi prepoznava pozitivne učinke bivanja $v$ zavodu, a na namestitev $v$ vzgojni zavod $s$ časovne distance ne gleda kot na obliko pomoči, ki je namenjena mlademu človeku, da se mu zagotovi varstvo, oskrbo in vzgojo oz. ponudi svobodo, ki jo zahteva njegov duševni in socialni razvoj (Krajnčan 2002, 163), temveč bivanje v instituciji doživlja kot hud vrez v življenje in življenjsko enovitost otroka (str. 163), kar lahko še povečuje pomanjkanje družinske podpore (Ibrahim in Howe 2011), kar se je dogajalo tudi pri Uli v obdobju prvega pripovedovanja.

Glede odnosa z materjo v zapisu pripoveduje, da sta se zaradi materine opitosti velikokrat sprli ter da ji pogovori z njo niso bili v pomoč. Od matere je pričakovala lepo besedo, spodbudo. Ker tega ni dobila, so bila njena pričakovanja porušena ter s tem izgubljena volja, da bi se tudi sama spremenila, večkrat je zaradi tega tudi begala. Vendar pa $v$ tem obdobju, ki se časovno povezuje z obdobjem bivanja v zavodu, izpostavi odnos s teto, za katero pove, da je bila njena »lučka v temi«. »Pomagala mi je, da sem spremenila pogled na svet, da sem dojela, da nisem sama.« Sočasno z izražanjem hvaležnosti do tete pa je kritična do matere, kar razumemo iz izjave: „Čeprav to ni bilo njeno mesto, na tem mestu bi morala biti moja mama.»

Ob drugem pripovedovanju njene življenjske zgodbe smo Ulo prosili, da se pri pisanju osredotoči na razvoj svoje poklicne poti ter predstavi svoje trenutno življenje, kljub temu pa je velik del besedila namenila opisovanju dogajanj v odnosu s svojimi starši. Obširen del besedila nameni natančnim opisom dogodkov iz obdobja, ko je izgubila svojega očeta, ki ga zaključi z izjavo: »Nikoli ga ni bilo, nikoli ni bil del mojega življenja, pa je kljub vsemu bil moj idol, moj ponos, imela sem ga neizmerno rada.« Podobno tudi veliko prostora nameni opisu zdravljenja materine odvisnosti od alkohola, pri katerem jo je spremljala in ga je mati tudi uspešno zaključila. Pripoveduje o tem, da je bila ona tista, na katero se je mama obrnila, ko je potrebovala pomoč, ter tudi o tem, da se je sama na njene prošnje odzvala takoj: »V kraju bivanja matere sem bila v 40 minutah. ${ }^{6}$

$\checkmark$ povezavi s pomočjo ožjim družinskim članom so prepoznali vezi, ki jih mladostniki z izkušnjo bivanja $v$ instituciji čutijo $s$ starši in so, ne glede na zanemarjanje in zlorabo, ki so ju utrpeli z njihove strani, visoko pomembne, zaradi česar jim, namesto da bi starše obtoževali za to, kar so jim storili, nudijo fizično in čustveno pomoč in oporo (Melkman idr. 2015), ${ }^{7}$ kar velja tudi za Ulo.

\footnotetext{
${ }^{6}$ Realen čas vožnje med krajem, kjer je živela Ula, ter krajem, kjer je živela njena mama, je ena ura in 11 minut (po izračunu na Google Maps).

${ }^{7}$ Raziskava se nanaša na mladostnike z izkušnjo bivanja v instituciji, ki so vključeni v visokošolsko
} 
Ula v nadaljevanju poroča, da je od tega, ko se je njena mama ozdravila, minilo pet let ter da se mama sedaj trudi, da bi Ulinima otrokoma dala to, kar ni zmogla njej: »Nikoli ni zmogla meni dati ljubezni, varnosti, stabilnost in zaščite.« Iz česar povzemamo, da je bilo pomanjkanje naštetega v otroštvu tudi razlog za Ulino namestitev $v$ zavod.

Ula v drugem besedilu zapiše svoje videnje oz. doživljanje matere, ki je drugačno kot v obdobju, ko je vzgojno institucijo zapuščala: »Mame ne krivim v taki meri, kot sem jo pred leti, niti ne želim več iskati krivca, ampak sem hvaležna prav za vsako rano, preizkušnjo ... Težko je biti mama in zelo hitro se lahko kaj zalomi.»

V življenjskih zgodbah, zapisanih v letih 2014 in 2021, se Uline misli pogosto vračajo k opisovanju matere in njunega odnosa. Iz tega razumemo, da je ta odnos, ki je bil daljši čas neprimeren oz. Ula s strani matere ni dobila, kar je potrebovala in pričakovala, močno zaznamoval njeno življenje, ter ocenjujemo, da je tudi vplival na njene odločitve na področju izobraževanja ter zaposlitve.

Glede na Ulin način pripovedovanja o materi je razvidno, da si je ves čas želela, da bi bila mati aktivno prisotna v njenem življenju, da bi ji zagotavljala pomoč in podporo, ki ju je potrebovala.

$\checkmark$ povezavi s podporo matere so $v$ okviru preučevanja subjektivne ocene dobrega počutja mladostnikov, ki so zaključili institucionalno oskrbo, med katerimi eno od postavk predstavlja tudi socialna podpora (družina, vrstniki, kariera), ugotovili, da pozitiven odnos z materjo presega ostale tipe podpore, da je ta podpora najmočnejša ter tudi da pozitiven odnos z materjo leto dni po odhodu iz zavoda pozitivno prispeva k njihovim življenjem. Na podlagi ugotovitev avtorji raziskave domnevajo, da se pri mladostnikih, ki imajo pozitiven odnos $z$ materjo ob koncu bivanja $v$ zavodu, po odhodu iz njega ta odnos nadaljuje, kar mladim omogoča, da se lahko takrat, ko starše potrebujejo, nanje obrnejo po pomoč in podporo (Dinisman idr. 2013). ${ }^{8}$

Iz dejstva, da Ula v svojih pripovedih na več mestih potek dogodkov povezuje z odnosom z materjo, ter tudi iz opisane spremembe $v$ njunem odnosu po materinem zdravljenju odvisnosti od alkohola vidimo, da je ves čas pogrešala odnos z materjo in si na različne načine prizadevala, da bi ga uspeli vzpostaviti, a pri tem ni bila uspešna, vse dokler ključnega koraka (zdravljenje odvisnosti od alkohola) k temu ni naredila mama. Sklepamo, da je v tem

izobraževanje $v$ Nemčiji in na Irskem, a glede na Ulino zaključeno srednjo šolo ter njen interes za vključitev v nadaljevanje šolanja menimo, da lahko ugotovitve raziskave primerjamo tudi z njenim položajem.

${ }^{8}$ Raziskava je bila opravljena med izraelskimi mladostniki. 
primeru vpliv odnosa z materjo na oblikovanje izobrazbenega oz. zaposlitvenega statusa pomemben. Slab odnos z materjo zavira oblikovanje mladostničinega optimalnega izobrazbenega oz. poklicnega statusa.

\section{Sklepne misli}

Danes ima Ula z materjo primeren odnos, do česar je prišlo, ko je mati uspešno zaključila zdravljenje zaradi prekomernega uživanja alkohola. V obdobju, ko je bila Ula vključena v zavodsko oskrbo, se mati zanjo ni zanimala, tudi ko je zavod zapustila, je živela pri teti. Ob tem se sprašujemo, ali je bila mati seznanjena ter usmerjena v primerne oblike pomoči s področja prekomernega uživanja alkohola. Razmišljanje v povezavi s tem se nadaljuje v smeri, katere sploh so primerne oblike pomoči za navedene materine težave ter kako posameznika prepričati, da potrebuje pomoč, če tega ne prepozna sam. Odgovor na postavljeno vprašanje se kaže v smeri, da je to odločitev vsakega posameznika, še posebej če gre za programe, kjer je vključitev prostovoljna.

Na področju zaposlovanja oz. sodelovanja z Zavodom za zaposlovanje ugotavljamo, da se $v$ programe aktivne politike zaposlovanja mladostniki $z$ izkušnjo bivanja v instituciji lahko vključujejo zaradi ranljivosti, ki jo izkazujejo $z$ brezposelnostjo in ob upoštevanju starostnega pogoja, ter ne zaradi bivanja v vzgojnem zavodu, kar jih je prikrajšalo za normalno družinsko življenje. To kaže, da v okviru aktivne politike zaposlovanja niso prepozni kot ranljiva skupina in da so na področju iskanja zaposlitve s tega vidika spregledani. Do takšnih ugotovitev so prišli tudi drugi avtorji (Leskošek 2009, 213), ki ugotavljajo, da je sicer za kritiko aktivne politike zaposlovanja potrebnega manj prostora kot pred leti, a vseeno program spregleda raznovrstne skupine mladih, zaradi česar je njihov položaj v družbi neenak.

Kljub temu pa velja na tem mestu opozoriti, da v slovenskem prostoru do sedaj tudi sicer ni bilo primernih oblik pomoči, namenjenih mladostnikom z izkušnjo bivanja v instituciji, ki bi jim ponovno vključevanje v družbo olajšale ter jih pri teh korakih tudi spremljale.

$\checkmark$ povezavi z vzpostavljanjem odnosa med mladostniki in starši po zaključenem bivanju ugotavljamo, da je delo s starši šibko oz. ga ni. Najnovejša zakonodaja (Zakon o obravnavi otrok in mladostnikov s čustvenimi in vedenjskimi težavami in motnjami v vzgoji in izobraževanju (2020)) na področju obravnave otrok in mladostnikov s čustvenimi in vedenjskimi težavami in motnjami vključuje določbo o pripravi načrta sodelovanja in svetovanja staršem ter družini otroka ali mladostnika, ki poteka v strokovnem centru ali na domu družine in ki lahko vključuje še druge oblike aktivnosti v strokovnem centru, vključitev v šolo za starše, v terapevtsko skupino idr. 
Ker gre za najnovejšo normativno ureditev na tem področju, ki je zelo zaželena ter predvsem potrebna, o izkušnjah in rezultatih dela v zvezi s tem žal še ne moremo poročati. Lahko pa sklepamo, da je bila oblikovana ravno zaradi tega, ker se je na tem področju že dalj časa zaznavala vrzel pri zagotavljanju oblik pomoči, kar smo v naši raziskavi prepoznali tudi sami.

\section{Literatura}

Arnau-Sabatés, L., in R. Gilligan. 2015. „What Helps Young Care Leavers to Enter the World of Work? Possible Lessons Learned from an Exploratory Study in Ireland and Catalonia." Children and Youth Services Review 53:185-191.

Bujanović Pastuavić, R., in J. Bašić. 1982. »Povezanost efikasnosti resocijalizacije i zavodskog tretmana maloljetnika u SR Hrvatskoj.»Defektologija 18 (1-2): 145-151.

Cencič, M. 2001. »Življenjska zgodovina na pedagoškem področju.« Sodobna pedagogika 52 (2): 50-62.

Dinisman, T., A. Zeira, Y. Sulimani-Aiden in R. Benbenishty. 2013. „The Subjective Well-Being of Young People Aging Out of Care." Children and Youth Services Review 35 (10): 1705-1711.

Dutta, S. 2017. »Life after Leaving Care: Experiences of Young Indian Girls."Children and Youth Services Review 73:266-273.

Goodson, I. F., ur. 1992. Studying Teachers Lives. London: Routledge.

Groinig, M., in S. Sting. 2019. »Educational Pathways In and Out of Child and Youth Care: The Importance of Orientation Frameworks that Guide Care Leavers Actions along Their Educational Pathway. "Children and Youth Services Review 101:42-49.

Harder, A. T., E. J. Knorth in M. Kalverboer. 2011. »Transition Secured? A FallowUp Study of Adolescents Who Left Secure Residental Care." Children and Youth Serivces Review 33 (12): 2482-2488.

Hiles, D., D. Moss, J. Wright in R. Dallos. 2013. "Young People's Experience of Social Support during the Process of Leaving Care: A Review of the Literature." Children and Youth Services Review 35 (12): 2059-2071.

Höjer, I., in Y. Sjöblom. 2011. »Procedures when Young People Leave Care Views of 111 Swedish Social Services Managers." Children and Youth Services Review 33 (12): 2452-2460.

Ibrahim, R. W., in D. Howe. 2011. »The Experience of Jordanian Care Leavers Making the Transition from Residential Care to Adulthood: The Influence of a Patriarchal and Collectivist Culture." Children and Youth Services Review 33 (12): 2469-2474.

Jackson, S., in C. Cameron. 2012. »Leaving Care: Looking Ahead and Aiming Higer.» Children and Youth Services Review 34 (6): 1107-1114.

Kovačević, V. 1982. „Uspješnost resocijalizacije određenih na osnovi psiholoških, socioloških i tretmanskih varijabli.« Defektologija 18 (1-2): 111-121. 
Krajnčan, M. 2002. »Nekateri vidiki v zaznavanju, definiranju in odločanju za napotitev otroka v vzgojni zavod.« V Vizije slovenske kriminologije, ur. G. Meško, 163-196. Ljubljana: Ministrstvo za notranje zadeve Republike Slovenije in Visoka policijsko varnostna šola.

- 2006. Na pragu novega doma: oddaja otrok v vzgojni zavod. Ljubljana: Pedagoška fakulteta.

Krajnčan, M., in P. Šoln Vrbinc. 2015. »Med preteklostjo in prihodnostjo zavodske vzgoje.« V Moči, izzivi, vizije vzgojnih zavodov, ur. A. Kobolt, 11-36. Ljubljana: Pedagoška fakulteta.

Leskošek V. 2009. »Zaposlitvene možnosti mladih."Socialno delo 48 (4): 207214.

Malmberg, L.-E., in J. Trempala. 1997. »Anticipated Transition to Adulthood: The Effect of Educational Track, Gender, and Self-Evaluation on Finnish and Polish Adolescents' Future Orientation. "Journal of Youth and Adolescence 26 (5): 517-537.

Melkman, E., Y. Mor-Salwo, K. Mangold, M. Zeller in R. Benbenishty. 2015. »Care Leavers as Helpers: Motivations for and Benefits of Helping Others." Children and Youth Services Review 54:41-48.

Ministrstvo za delo, družino, socialne zadeve in enake možnosti. B. I. »Denarna socialna pomoč.»https://www.gov.si/teme/denarna-socialna-pomoc/.

- 2020. „Smernice za izvajanje ukrepov aktivne zaposlovanja za obdobje 2021-2025." Ministrstvo za delo, družino, socialne zadeve in enake možnosti, Ljubljana.

—. 2021. »Katalog aktivne politike zaposlovanja.« Ministrstvo za delo, družino, socialne zadeve in enake možnosti, Ljubljana.

National Audit Office. 2015. "Care Leavers' Transition to Adulhood." Report by the Comptroller and Auditor General. https://www.nao.org.uk/wpcontent/uploads/2015/07/Care-leavers-transition-to-adulthood.pdf.

Patton, Q. M. 2002. Qualitative Research \& Evaluation Methods. 3. izd. Thousand Oaks, CA: Sage.

Radić Bursać, S., in I. Jeđud Borić. 2013. »Končno svobodni? - Perspektive mladih o samostojnem življenju po odhodu iz mladinskega doma."Socialna pedagogika 17 (3-4): 247-270.

Sagadin, J. 2001. »Pregledno o kvalitativnem empiričnem pedagoškem raziskovanju.« Sodobna pedagogika 52 (2): 10-25.

Skalar, V. 1995. »Oblike zunajdružinske vzgojne pomoči v Sloveniji.«Iskanja: vzgoja prevzgoja 12 (14): 22-30.

Škoflek, I. 1989. »Evaluacija procesov in efektov zavodskega tretmana otrok in mladostnikov z motnjami vedenja v socialistični Republiki Sloveniji.« Doktorska disertacija, Univerza v Beogadu.

Zakon o obravnavi otrok in mladostnikov s čustvenimi in vedenjskimi težavami in motnjami v vzgoji in izobraževanju (ZOOMTVI). 2020. Uradni list Repu- 
blike Slovenije, št. 200. https://www.uradni-list.si/1/objava.jsp?sop=2020 $-01-3628$.

Zakon o socialno varstvenih prejemkih (ZSvarPre). 2010. Uradni list Republike Slovenije, št. 61. https://www.uradni-list.si/1/objava.jsp?sop=2010-01-3350. Zakon o urejanju trga dela (ZUTD). 2010. Uradni list Republike Slovenije, št. 80. https://www.uradni-list.si/1/objava.jsp?sop=2010-01-4304.

Zakon o uveljavljanju pravic iz javnih sredstev (ZUPJS). 2010. Uradni list Republike Slovenije, št. 62. https://www.uradni-list.si/1/objava.jsp?sop=2010-01 -3387 .

Žižak, A. 1982. »Odnos maloljetnih delikvenata prema porodici nakon zavodskog tretmana." Defektologija 18 (1-2): 153-159.

Žižak, A., N. Koller-Trbovič in I. Jeđud. 2005. »Samoizkaz djece i mladeži u riziku i/ili s poremećajima u ponašanju o budućnosti.« Djete i društvo 7 (1): 117138.

\section{The Importance of the Mother's Relationship in Regulating the Employment Status of Adolescents That Experienced Living in a Residential Care Facility}

In the paper, we first present the problem of reintegration of adolescents into the social environment after completing their stay in a residential care facility, with an emphasis on the importance of the relationship with and support of their parents (mother) and regulating employment status. In the qualitative research part of this paper, we analyse the example of the integration of an adolescent woman into the social environment after completing her stay in a residential care facility. The data, collected through writing a life story, shows that despite completing her secondary education, the adolescent was working as a cleaner, first illegally, later through a contract, and expressing her wish to study social pedagogy, which she is afraid to pursue. The mother was not interested in the adolescent for a long time. Later, when the mother successfully completed treatment for alcohol addiction, their relationship improved. On the basis of the adolescent's statements, it is concluded that poor support and the relationship of the mother with the adolescent influenced her decisions in the field of employment and education, in a direction where all her skills are not used.

Keywords: institutional care, employment, education, relationship with mother 